\title{
HAK DAN KEWAJIBAN WAJIB PAJAK DALAM PENYELESAIAN SENGKETA PERPAJAKAN DI PENGADILAN PAJAK
}

\author{
Wan Juli \\ Joko Nur Sariono \\ Fakultas Hukum Universitas Wijaya Kusuma Surabaya \\ e-mail:wan.juli73@yahoo.com
}

\begin{abstract}
ABSTRAK
Penyelesaian sengketa perpajakan di Pengadilan Pajak pada umumnya berawal dari adanya penerbitan suatu keputusan yang dilakukan oleh pihak Direktorat Jenderal Pajak. Upaya penyelesaian sengketa ini dibedakan menjadi dua upaya yaitu banding yang dilakukan atas Surat Keputusan Keberatan dan gugatan yang diajukan atas keputusan lain selain keputusan keberatan dan keputusan terkait dengan upaya penagihan pajak. Hak dan kewajiban Wajib Pajak dalam upaya banding dan gugatan ini dalam beberapa hal menjadi tidak terlindungi. Adanya pembatasan kompetensi absolut mengakibatkan permohonan Wajib Pajak yang tidak dapat dipertimbangkan atau tidak dapat diproses lebih lanjut. Hukum acara yang berbeda (dibandingkan dengan Hukum Acara Peradilan Tata Usaha Negara) menimbulkan kerancuan dan ketidakpastian dan terkesan bahwa upaya penyelesaian sengketa di Pengadilan Pajak sangat ekslusif dari Peradilan Tata Usaha Negara. Selain itu, upaya hukum lebih lanjut berupa kasasi juga tertutup karena atas putusan Pengadilan Pajak tidak dapat diajukan banding ataupun kasasi sehingga upaya lebih lanjut atas Putusan Pengadilan Pajak hanyalah Peninjauan Kembali di Mahkamah Agung.
\end{abstract}

Kata Kunci: penyelesaian sengketa, banding, gugatan, Pengadilan Pajak, kompetensi absolut.

\begin{abstract}
The tax dispute resolution at the Tax Court generally begins with the issuance of Directorate General of Taxes Decision. Dispute resolution efforts comprise of two different arenas: appeal agains the Objection decision and lawsuit against Decisions related to the tax collection and Decisions other than objection decision. To some extend, it is clear that the rights and obligations of the Taxpayer are not protected. The limitation on the absolute competence may result in the Decision of Tax Court which stated that the application cannot be considered or processed further. Different Laws on the procedures (compared to the Procedures in Administrative Court) may result in the legal uncertainty and give an impression that the dispute resolution effort at the Tax Court is separate and exclusive from the Administrative Court. Furthermore, further legal effort, i.e appeal to the Supreme Court is also impossible because the only legal effort available after the tax Court Decision is only Reconsideration at the Supreme Court.
\end{abstract}

Keywords: dispute resolution, appeal, lawsuit, Tax Court, and Absolute Competence.

\section{PENDAHULUAN}

Secara umum, sengketa dalam bidang perpajakan bermula dengan ketetapan pajak yang diatur dalam Bab III (Pasal 12-15, dan Pasal 17 A-E) UndangUndang Nomor 6 Tahun 1983 tentang Ketentuan Umum dan Tata Cara Perpajakan sebagaimana telah diubah terakhir dengan Undang-Undang Nomor 16
Tahun 2009 (selanjutnya disebut UU KUP). Wajib Pajak (selanjutnya disingkat WP) yang tidak setuju dengan ketetapan pajak pada intinya dapat mengajukan permohonan keberatan sebagaimana diatur dalam Pasal 25 dan 26 UU KUP atau permohonan penghapusan atau pengurangan sanksi atau pun pembatalan ketetapan 
yang tidak benar sebagaimana diatur dalam Pasal 36 UU KUP (PK-36).

Upaya keberatan merupakan upaya administrasi awal dalam penyelesaian sengketa administrasi di bidang perpajakan (yaitu berupa prosedur keberatan) yang mana pihak yang memutus sengketa ini adalah pihak yang menerbitkan ketetapan yang disengketakan itu sendiri, yakni pihak Direktorat Jenderal Pajak (yang selanjutnya diseut DJP). Dengan demikian, hakikat hukum upaya keberatan pada intinya adalah suatu penyelesaian sengketa yang ditangani oleh pejabat yang mengeluarkan ketetapan pajak yaitu DJP sendiri.

Perbedaan prinsip antara upaya keberatan dan PK-36 adalah bahwa dalam keberatan terkandung persengketaan antara WP dengan pihak fiskus dalam penerbitan Surat Ketetapan Pajak (selanjutnya disingkat SKP) ataupun dengan pihak lain dalam kaitannya dengan pemotongan atau pemungutan pajak yang dilakukan oleh pihak lain itu, sementara upaya PK-36 ini tidak ada sengketa dan sifatnya hanyalah permohonan kepada DJP untuk mengurangkan sanksi administrasi ataupun ketetapan pajak yang tidak benar dalam hal adanya kekhilafan WP atau adanya alasan pemaaf bahwa WP tidak bersalah. Apabila ditelusuri lebih lanjut, upaya PK-36 secara historis merupakan Ordonansi Keadilan (Soemitro, 1976: 80). Namun demikian, landasan adanya permohonan ampun ini tampaknya sudah tidak sekental UU KUP lama mengingat Pasal 36 ini juga mengatur tentang pembatalan hasil pemeriksaan pajak atau SKP yang penerbitannya tidak sesuai prosedur yaitu tanpa penyampaian SPHP ataupun tanpa pembahasan akhir hasil pemeriksaan.

Kedua upaya ini lebih dipandang sebagai upaya administrasi biasa dalam konteks Peradilan Administrasi. Hal ini disebabkan karena lembaga pemutus dalam upaya keberatan maupun PK-36 adalah juga lembaga yang menerbitkan ketetapan pajak. Kedua upaya ini memang dalam beberapa hal yang terbatas memberi hak kepada WP untuk memperoleh keadilan. Namun dalam banyak hal karena tidak adanya independensi lembaga pemutus sengketa, kedua upaya ini sama sekali tidak memberi kepastian perlindungan hukum terhadap WP.

Tulisan ini akan membahas mengenai hak dan kewajiban WP dalam upaya penyelesaian sengketa pajak di Peradilan Administrasi yaitu di Pengadilan Pajak. Pembahasan akan dimulai dengan paparan mengenai hak dan kewajiban WP dalam konteks hukum pajak, konsep peradilan administrasi, dan hak serta kewajiban WP dalam penyelesaian sengketa di Pengadilan Pajak.

\section{PEMBAHASAN}

\section{Tinjauan Umum Mengenai Hak dan Kewajiban Wajib Pajak}

Pandangan filosofis klasik mengenai pajak sebenarnya dapat ditelusuri dari adanya teori kedaulatan yang dianut oleh penganut paham hukum positif. Kedaulatan dalam teori ini maksudnya adalah kekuasaan tertinggi, absolut dan tidak ada lagi instansi lain yang dapat mengendalikannya. Kekuasaan ini dapat mengatur warga negara, tujuan negara, dan berbagai aspek pemerintahan, dan melakukan berbagai tindakan dalam suatu negara termasuk didalamnya adalah memungut pajak (Fuady, 2013:91). Teori kedaulatan ini apabila dikaitkan dengan pajak tercermin dalam sifat memaksa dalam pajak. Sifat memaksa ini juga tercermin dari beberapa definisi tentang pajak seperti yang misalnya diungkapkan oleh P.J.A. Adriani, Rochmat Soemitro, dan Soeparman Soemahamidjaja (Brotodihardjo, 2008:2). Cerminan dari sifat memaksa ini adalah adanya sanksi bagi siapa saja yang melanggar dan sanksi ini menimbulkan kewajiban dan adanya pertanggungjawaban hukum (Kelsen, 2006:96).

Sejalan dengan adanya sanksi dalam hukum pajak ini, petugas pajak (DJP) sebagai organ negara diberikan suatu hak untuk menjalankan wewenang secara hukum ini. Hak inilah yang disebut dengan hak refleks yang dihubungkan dengan kewajiban-kewajiban yang disyaratkan oleh negara (Kelsen, 2006:341). Di lain pihak, WP, selain karena adanya sanksi yang secara normatif bersifat memaksa, juga terikat dengan adanya hukum pajak ini secara psikologis sesuai dengan teori self-obligation (selbstverpflichtung) yang diungkapkan oleh Georg Jellinek (von Bernstorff, 2012:659-675). Teori ini menekankan sifat melekatnya hukum pada manusia secara psikologis. Hal ini menjadi indikator validitas berdasarkan keyakinan WP yang menjadi pihak utama kepada siapa hukum pajak itu ditujukan. Sebagai imbangan dari kewajiban pajak yang bersifat memaksa ini, hukum pajak juga menyediakan dan negara menjamin hak-hak tertentu bagi WP (Fuady, 2013:105). Tujuan dari pengaturan ini adalah untuk menciptakan sistem keteraturan yang baik dan tertib sesuai dengan konsep keteraturan hukum (Marzuki, 2008:79-85). 
Pandangan lain tentang hakikat hukum pajak adalah sebagaimana disampaikan oleh Rochmat Soemitro yang memandang hukum pajak dalam aspek hubungan hukum antara WP dan pihak fiskus. Secara spesifik, pandangan ini melihat dari sisi hak dan kewajiban masing-masing pihak yaitu siapa yang berhak memungut pajak, apa kewajiban pemungut pajak terhadap WP, siapa WP dan apa hak dan kewajiban WP terhadap fiskus. Landasan filosofis dari pendapat ini adalah bahwa pajak dianggap sebagai suatu perikatan antara WP dengan pihak fiskus yaitu perikatan yang timbul karena undang-undang yang mewajibkan pihak yang memenuhi syarat (tatbestand) untuk membayar sejumlah tertentu kepada negara yang dapat dipaksakan tanpa mendapat imbalan (kontra-prestasi) secara langsung (Soemitro, 1990:50-51).

Pajak termasuk perikatan yang lahir demi undangundang (timbul dari undang-undang saja). Cerminan dari aspek ini, misalnya, adalah WP mempunyai kewajiban membayar pajak (schuld) dan apabila WP tidak mau membayar pajak tersebut, maka WP dianggap membiarkan harta bendanya diambil oleh negara sebanyak hutang pajak tersebut (haftung) (Badrulzaman, Sjahdeini, Soepraptomo, Djamil, dan Soenandar, 2001:8). Secara sederhana hak dan kewajiban ini dapat diklasifikasikan dalam dua bagian yaitu dalam lingkup hukum (umum) yang diistilahkan dengan legal rights dan dalam lingkup administratif yang diistilahkan dengan administrative rights.

Hak-hak hukum mencakup hak-hak yang berkaitan dengan keabsahan tertentu (specific validity), pelaksanaan dan aplikasi dari hukum pajak. Hak-hak ini didasarkan pada prinsip hukum pada umumnya dan substansi yang terkandung dalam hukum tersebut. Widodo dan Djefris (2008:67) menyebutkan bahwa hak administratif WP adalah hak-hak umum bagi WP dalam melaksanakan kewajibannya untuk mematuhi ketentuan hukum yang berlaku dan menginginkan adanya keadilan dan efisiensi dalam operasional sehari-hari administrasi perpajakan, pemungutan pajak dan proses penyelenggaraannya.

Kedua pendapat ini memang tidak menyebutkan kewajiban administratif WP karena yang menjadi fokus perhatian adalah hak WP. Namun hal ini tidak dapat diinterpretasikan bahwa dalam lingkup administratif, tidak ada kewajiban WP. Justru sebaliknya dalam suatu lingkup hak tertentu, ternyata terdapat kewajiban WP yang telah melekat.

\section{Peradilan Administrasi}

Peradilan Administrasi diartikan sebagai peradilan yang menyelesaikan semua sengketa administrasi baik yang dilakukan oleh kekuasaan kehakiman (administratieve rechtspraak), maupun oleh kekuasaan administrasi sendiri (quasi-rechtspraak) (Wijoyo, 2005:4). Upaya keberatan dapat dianggap sebagai penyelesaian sengketa melalui peradilan administrasi semu karena ditangani oleh lembaga administrasi. Upaya banding dan gugatan merupakan penyelesaian sengketa melalui peradilan administrasi murni. Sjachran Basah (2010:30) menyatakan bahwa suatu peradilan harus memenuhi beberapa unsur, yaitu:

Pertama, Adanya aturan hukum yang dapat diterapkan pada persoalan. Unsur pertama ini sebenarnya diwujudkan dengan adanya Undang-Undang Pajak. Aspek hukum material dibahas dalam Undang-Undang Pajak yang bersangkutan. Jika terkait dengan Pajak Penghasilan (PPh), maka akan diatur dalam UndangUndang Nomor 36 Tahun 2008 tentang Perubahan Keempat atas Undang-Undang Nomor 7 Tahun 1983. Demikian pula dengan Pajak Pertambahan Nilai (PPN), ketentuan materialnya diatur dalam UU PPN, yakni Undang-Undang Nomor 42 Tahun 2009 tentang Perubahan Ketiga atas Undang-Undang Nomor 8 Tahun 1983 tentang Pajak Pertambahan Nilai Barang dan Jasa dan Pajak Penjualan atas Barang Mewah.

Kedua, Adanya suatu sengketa hukum yang konkret. Unsur ini terkait dengan sengketa yang diajukan dalam permohonan banding dan gugatan. Sejatinya, yang menjadi pokok sengketa dalam banding adalah sengketa yang dikemukakan WP dalam permohonan keberatan yang seharusnya diperhitungkan dan diputus dalam keputusan keberatan (Penjelasan Pasal 31 ayat (2) Undang-Undang Pengadilan Pajak). Sengketa pada saat keberatan adalah mengenai isi atau materi dari ketetapan pajak (Penjelasan Pasal 25 ayat (1) UU KUP). Dengan menggunakan model penalaran sillogisme, yang menjadi pokok sengketa dalam hal banding adalah mengenai materi atau isi dari ketetapan pajak. Sebaliknya pokok sengketa dalam hal gugatan adalah aspek formal dari suatu ketetapan atau aspek teknis pelaksanaan peraturan perpajakan selain keberatan. Namun demikian, hal ini tampaknya tidak berlaku dengan sangat ketat mengingat dalam proses banding ataupun gugatan tetap ada pengujian pemenuhan aspek formal dari ketetapan yang disengketakan. 
Ketiga, Ada sekurang-kurangnya dua pihak (audi alterum partem) yang terlibat. Dalam sengketa perpajakan tolok ukur subjek selalu sama yaitu antara rakyat (WP) dan pemerintah (diwakili DJP).

Keempat, Adanya badan peradilan yang berwenang memutus sengketa (nemo index in causa sua). Dalam konteks banding dan gugatan badan peradilan yang memutus ini adalah Pengadilan Pajak yang telah diberi wewenang sesuai dengan Undang-Undang Nomor 14 Tahun 2002 tentang Pengadilan Pajak (Lembaran Negara Republik Indonesia Tahun 2002 Nomor 27 tanggal 12 April 2002) (selanjutnya disebut UU PP).

Kelima, Terdapat hukum formal dalam rangka menerapkan hukum (rechtstoepassing) dan menemukan hukum (rechtsvinding) in concreto untuk menjamin ditaatinya hukum material (penjelasan poin pertama) di atas. Secara singkat, aspek formal terkait dengan prosedur yang ditempuh oleh WP dalam melakukan upaya penyelesaian sengketa yang dalam konteks upaya lanjut dari upaya administrasi adalah upaya banding atau gugatan. Prosedur pemenuhan aspek formal terkait dengan hukum acara pada intinya adalah aturan-aturan hukum yang diciptakan untuk mempertahankan hukum material. Dalam konteks upaya banding, hukum formal ini diatur dalam Pasal 27 UU KUP dan Pasal 35-39 UU PP, sedangkan dalam konteks gugatan diatur di Pasal 23 ayat (2) UU KUP dan Pasal 40-43 UU PP. Unsur terakhir ini yang menjadi fokus dalam aspek formal ini, mengingat peradilan tanpa hukum formal akan cenderung bersifat liar karena tidak ada batas-batas yang jelas dalam melakukan wewenangnya (Wijoyo, 2005:15).

\section{Hak Ikat dan Kedudukan Pengadilan Pajak}

Sebelum membahas mengenai hukum acara dalam penyelesaian sengketa di Pengadilan Pajak, adalah sangat penting untuk memahami hakikat dan kedudukan Pengadilan Pajak yang menjalankan fungsi yudikatif terkait dengan sengketa perpajakan. Sesuai dengan Penjelasan Pasal 27 ayat (1) Undang-Undang Nomor 48 Tahun 2009 tentang Kekuasaan Kehakiman, hakikat Pengadilan Pajak pada intinya adalah sebagai peradilan khusus di lingkungan Peradilan Tata Usaha Negara. Dengan adanya ketentuan dapat diharapkan bahwa prinsip-prinsip dalam penyelesaian sengketa di bidang perpajakan berakar dari sengketa TUN. Namun demikian, harapan ini tidak sepenuhnya terlaksana dengan alasan sebagai berikut:
Pertama, Ketentuan Pasal 27 ayat (1) UndangUndang Nomor 48 Tahun 2009 ini tampaknya dilatarbelakangi oleh banyaknya kritik mengenai kedudukan Pengadilan Pajak. John Eddy (2003) menyebutkan bahwa UU PP bertentangan dengan Pasal 24 ayat (2) UUD 1945 maupun Undang-Undang Nomor 14 Tahun 1970 sebagaimana telah diubah dengan Undang-Undang Nomor 35 Tahun 1999 (Undang-Undang Kekuasaan Kehakiman Sebelum Perubahan). Logika dasar dari pendapat ini adalah bahwa dalam UUD 1945 maupun UU Kekuasaan Kehakiman sebelum perubahan sama sekali tidak menyebut adanya Pengadilan Pajak. Faktor kedua sehubungan dengan alasan ini adalah bahwa dalam Permohonan Pengujian Undang-Undang Nomor 14 Tahun 2002 terhadap UUD 1945 di Mahkamah Konstitusi, kedudukan pengadilan pajak sebagai spesialis dari PTUN juga dipertanyakan. Namun demikian, dalam Putusan Perkara Nomor 004/PUUII/2004, MK menolak permohonan pengujian UU PP ini. Dengan demikian, penulis menduga bahwa ketentuan Pasal 27 ayat (1) Undang-Undang Nomor 48 Tahun 2009 ini sengaja disebutkan untuk mendukung konstitusionalitas Pengadilan Pajak, sekalipun hal ini terkesan janggal karena UU PP diterbitkan terlebih dahulu daripada Undang-Undang Nomor 48 Tahun 2009.

Kedua, Permasalahan kedua terkait dengan UU PP adalah mengenai sifat putusan Pengadilan Pajak yang merupakan putusan terakhir dan dapat langsung diajukan Peninjauan Kembali ke Mahkamah Agung (selanjutnya disingkat MA). Hal ini sebenarnya selain memangkas hak WP juga bertentangan dengan PTUN yang mana atas putusannya masih dapat diajukan Kasasi dan baru setelah itu Peninjauan Kembali. Hal ini juga ditolerir oleh MK dengan dalil bahwa upaya Kasasi maupun Peninjauan Kembali juga sama-sama ditangani MA. Dalil MK ini tampaknya mengabaikan fakta bahwa dalam upaya Peninjauan Kembali terdapat beberapa pembatasan (adanya syarat-syarat sebagaimana diatur dalam Pasal 91 UU PP), sementara dalam upaya Kasasi tidak ada batasan demikian.

Ketiga, Selanjutnya adalah masalah pembinaan sebagaimana diatur dalam Pasal 5 ayat (1) UU PP bahwa pembinaan teknis peradilan dilakukan oleh MA, sedangkan pembinaan organisasi, administrasi, dan keuangan dilakukan oleh Departemen Keuangan. Hal ini selain rawan konflik kepentingan juga 
bertentangan dengan prinsip pemisahan kekuasaan bahwa kekuasaan eksekutif harus terpisah dengan kekuasaan yudikatif. Namun demikian, masalah campur tangan kekuasaan eksekutif dalam lingkup kekuasaan yudikatif memang merupakan permasalahan inheren praktik serta penegakan hukum di Indonesia (Marbun, 2012).

Keempat, Apabila dicermati hukum acara penyelesaian sengketa pajak di Pengadilan Pajak juga sangat berbeda dengan hukum acara PTUN sebagaimana dijelaskan dalam sub bagian berikut ini. Hukum acara ini menimbulkan pertanyaan sensitif mengenai apakah kedudukan Pengadilan Pajak merupakan lex specialis dari PTUN.

Beberapa faktor tersebut di atas menunjukkan bahwa hakikat dan kedudukan Pengadilan Pajak itu sendiri sebenarnya tidak terlalu kokoh sebagai peradilan khusus dari PTUN. Namun demikian, harus diakui bahwa Pengadilan Pajak ini pada hakikatnya merupakan peradilan murni (administratief rechtspraak), berbeda dengan lembaga sebelumnya yaitu MPP maupun BPSP yang tidak lebih merupakan upaya banding administrasi. Namun demikian, jelas sekali bahwa dalam UU PP ini sarat dengan motif kepentingan pemerintah untuk menjamin penerimaan pajak tanpa memperhatikan hak fundamental WP.

\section{Kompetensi Absolut Upaya Banding}

Selanjutnya, apabila upaya administratif ini tidak berhasil, WP dapat mengajukan banding yang diatur di Pasal 27 UU KUP ataupun gugatan yang diatur di Pasal 23 UU KUP ke Badan Peradilan Pajak yang dalam hal ini adalah Pengadilan Pajak. Sesuai dengan Pasal 27 ayat (1) UUKUP, upaya banding yang merupakan kompetensi absolut Pengadilan Pajak seharusnya sudah sangat spesifik yaitu hanya dapat diajukan atas Surat Keputusan Keberatan (Pudyatmoko, 2009:76). Hal ini juga sejalan dengan ketentuan Pasal 31 ayat (2) UU PP.

Perubahan yang signifikan dalam objek pengajuan banding berdasarkan UU KUP terletak pada penekanan Surat Keputusan Keberatan. Dalam Pasal 27 ayat (1) UU KUP, disebutkan bahwa permohonan Banding diajukan terhadap keputusan mengenai keberatannya yang ditetapkan oleh DJP. Secara logis, keputusan mengenai keberatan memiliki makna yang lebih luas daripada Surat Keputusan Keberatan karena keputusan mengenai keberatan tidak terikat pada bentuk dari suatu produk hukum keputusan keberatan dan dapat mencakup surat dinas biasa yang dikeluarkan oleh DJP terkait dengan permohonan keberatan WP. Hal ini dimungkinkan terjadi dalam hal surat permohonan keberatan WP tidak memenuhi persyaratan formal. Dengan demikian, interpretasi gramatikal dari ketentuan ini adalah bahwa objek surat yang diajukan banding dalam konteks UU KUP semakin sempit yaitu hanya mencakup suatu produk hukum formal yaitu Surat Keputusan Keberatan, sementara Surat Keputusan Keberatan ini hanya diterbitkan oleh DJP sepanjang permohonan keberatan WP memenuhi persyaratan formal sebagaimana diatur dalam Pasal 25 UU KUP dan PMK-9/PMK.03/2013.

Ketentuan mengenai objek permohonan Banding yang hanya mencakup Surat Keputusan Keberatan menyisakan permasalahan mengenai status Surat Dinas dari DJP yang diterima WP yang permohonan keberatannya tidak memenuhi persyaratan formal. Dalam praktik, persengketaan antara WP dan pihak fiskus dapat juga timbul mengenai persyaratan aspek formal pengajuan keberatan seperti misalnya:

Pertama, Penyebutan jumlah pajak terutang, jumlah pajak yang dipotong atau dipungut, atau jumlah rugi menurut perhitungan WP, apabila WP tidak menyebutkan secara eksplisit jumlah pajak menurut perhitungannya, namun telah menunjukkan angka perhitungan pajak dalam SKP (yang menunjukkan angka WP).

Kedua, Pihak yang berwenang menandatangani Surat Keberatan, apabila permohonan WP ditandatangani oleh pengurus dalam konteks Pasal 32 UU KUP. Permasalahan dalam pengertian pengurus ini adalah tidak hanya Direktur yang namanya tertera dalam Akta Perusahaan, namun juga mencakup orang yang nyata-nyata mempunyai wewenang ikut menentukan kebijaksanaan dan/atau mengambil keputusan dalam menjalankan perusahaan. Pembuktian mengenai apakah seseorang itu mempunyai wewenang ikut menentukan kebijaksanaan dan/atau mengambil keputusan dalam menjalankan perusahaan jauh lebih sulit daripada pembuktian mengenai keabsahan direktur yang cukup mengacu pada Akta Perusahaan. Karena itu dalam praktik bisa saja terjadi sengketa terkait dengan surat keberatan WP yang tidak ditandatangani oleh direksi sehingga permohonan keberatannya tidak dipertimbangkan oleh DJP.

WP yang tidak setuju terhadap surat dinas dari DJP ini praktis akan menghadapi masalah besar karena tidak adanya kejelasan mengenai upaya penyelesaian 
sengketanya. Hal ini disebabkan karena surat dinas ini dikeluarkan berdasarkan wewenang Pasal 25 ayat (4) UU KUP yang menyebutkan bahwa keberatan yang tidak memenuhi persyaratan tidak dianggap sebagai surat keberatan sehingga tidak dipertimbangkan. Konsekuensinya adalah bahwa surat dinas ini diterbitkan dalam lingkup pasal 25 UU KUP yang dikecualikan dari objek pengajuan gugatan.

Pendapat Pengadilan Pajak dalam kasus ini juga bervariasi, seperti misalnya dalam dua kasus yang hampir sama berikut ini: Pertama, WP sebelumnya mengajukan permohonan keberatan atas ketetapan pajak tahun pajak 2006 dengan surat permohonan yang ditandatangani namun tidak menunjukkan nama dan jabatan yang menandatangani surat keberatan itu. Surat keberatan ini awalnya ditanggapi oleh pihak DJP bahwa permohonan telah memenuhi ketentuan formal, namun kemudian pihak DJP mengeluarkan lagi surat dinas yang membatalkan surat sebelumnya dan menyatakan permohonan keberatan itu tidak memenuhi ketentuan formal. Terhadap surat dinas ini, pihak WP kemudian mengajukan banding kepada Pengadilan Pajak. Dalam Putusan Pengadilan Pajak Nomor 32465/ PP/M.XIII/15/2011, Pengadilan Pajak menyatakan tidak dapat menerima permohonan WP dengan alasan bahwa surat dinas itu bukan merupakan keputusan atas keberatan karena tidak mencantumkan sikap DJP atas materi atau isi dari ketetapan pajak melainkan hanya pemberitahuan tertulis terkait pengajuan keberatan WP. Dalam putusan ini, terjadi dissenting opinion yang mana salah satu hakim Pengadilan Pajak berpendapat bahwa surat dinas tersebut dianggap sebagai jawaban atas surat keberatan dari WP dan karena itu dapat diajukan Banding.

Kedua, WP mengajukan permohonan keberatan atas ketetapan pajak tahun pajak 2009 namun surat keberatan ini tidak ditandatangani oleh pengurus yang ada di Akta Perubahan Terakhir Perusahaan melainkan hanya ditandatangani oleh orang yang mendapat kuasa dari Direktur Utama. Seperti kasus sebelumnya, setelah menerima permohonan keberatan ini, pihak DJP menerbitkan surat dinas bahwa permohonan Wajib Pajak telah memenuhi ketentuan formal namun kemudian surat ini diralat oleh pihak DJP. WP kemudian mengajukan gugatan atas surat dinas ini. Dalam Putusan Pengadilan Pajak Nomor 37999/PP/M.I/99/2012, Majelis Hakim berpendapat bahwa surat dinas dari DJP yang digugat oleh WP pada intinya adalah keputusan yang berkaitan dengan pelaksanaan keputusan perpajakan yang ditetapkan berdasarkan Pasal 25 ayat (1) dan Pasal 26 UU KUP sehingga seharusnya diajukan melalui proses Banding dan tidak dapat diajukan gugatan sesuai Pasal 23 ayat (2) huruf c UU KUP.

Dari dua kasus tersebut di atas, jelas sekali bahwa atas keputusan yang sama yaitu Surat Dinas dari DJP bahwa permohonan keberatan WP tidak memenuhi ketentuan formal, Majelis Hakim Pengadilan Pajak tidak mempunyai pendapat yang seragam. Dalam kasus pertama pihak WP mengajukan upaya banding namun tidak dapat dipertimbangkan oleh Pengadilan Pajak yang berposisi bahwa upaya gugatan yang tepat. Sebaliknya, dalam kasus kedua, WP mengajukan upaya gugatan namun juga tidak dipertimbangkan oleh Pengadilan Pajak yang berpendapat bahwa upaya banding yang tepat.

\section{Kompetensi Absolut Upaya Gugatan}

Selain itu, sengketa yang menjadi wewenang upaya gugatan adalah sengketa atas pelaksanaan penagihan pajak atau keputusan pembetulan atau keputusan lainnya sebagaimana diatur dalam Pasal 23 ayat (2) UU KUP. Pasal 23 ayat (2) UU KUP memberikan beberapa objek yang dapat diajukan gugatan yaitu: 1. Pelaksanaan Surat Paksa, Surat Perintah Melaksanakan Penyitaan, atau Pengumuman Lelang; 2. Keputusan pencegahan dalam rangka penagihan pajak; 3 . Keputusan yang berkaitan dengan pelaksanaan keputusan perpajakan, selain yang ditetapkan dalam Pasal 25 ayat (1) dan Pasal 26 (yaitu keputusan keberatan yang menjadi domain upaya banding); serta 4. Penerbitan Surat Ketetapan Pajak atau Surat Keputusan Keberatan yang dalam penerbitannya tidak sesuai dengan prosedur atau tata cara yang diatur dalam ketentuan peraturan perundang-undangan perpajakan.

Pemerintah pada tanggal 29 Desember 2011 menerbitkan Peraturan Pemerintah Nomor 74 Tahun 2011 yang mengganti Peraturan Pemerintah Nomor 80 Tahun 2007 Untuk melaksanakan ketentuan dalam UUKUP ini. PP-74 ini secara substansial tidak mengubah mengenai kelayakan atau objek pengajuan banding. Namun demikian, PP-74 ini memberi interpretasi sepihak mengenai ketentuan Pasal 23 ayat 2 huruf c UU KUP tentang keputusan yang berkaitan dengan pelaksanaan keputusan perpajakan yang diajukan gugatan kepada badan peradilan pajak sehingga keputusan-keputusan berikut tidak lagi dicakup sebagai objek gugatan, yaitu: Surat ketetapan pajak 
yang penerbitannya telah sesuai dengan prosedur dan tata cara penerbitan; Surat keputusan pembetulan; Surat keputusan keberatan yang penerbitannya telah sesuai dengan prosedur dan tata cara penerbitan; Surat keputusan pengurangan sanksi administrasi; Surat keputusan penghapusan sanksi administrasi; Surat keputusan pengurangan ketetapan pajak; Surat keputusan pembatalan ketetapan pajak; dan Surat keputusan pengembalian pendahuluan kelebihan pajak.

Hal yang signifikan dari ketentuan ini adalah bahwa ketentuan ini bersifat membatasi hak WP dalam penyelesaian sengketa. Surat Ketetapan Pajak yang penerbitannya telah sesuai dengan prosedur dan tata cara dan surta keputusan keberatan yang penerbitannya telah sesuai dengan prosedur dan tata cara penerbitan memang sudah selayaknya tidak dapat diajukan gugatan karena SKP merupakan objek yang ditangani lembaga keberatan, sedangkan surat keputusan keberatan merupakan kompetensi lembaga banding. Namun untuk surat keputusan yang lain tidak seharusnya dihapuskan sebagai objek yang dapat diajukan gugatan. Beberapa pertimbangan terhadap hal ini adalah sebagai berikut: (IKPI, 2012)

Pertama, UU KUP sama sekali tidak memberi kewenangan khusus bagi peraturan setingkat peraturan pemerintah untuk memberikan batasan mengenai objek gugatan. Kedua, Dalam Pasal 12 Undang-Undang Nomor 12 Tahun 2011 tentang Pembentukan Peraturan Perundang-undangan ditegaskan bahwa materi muatan peraturan pemerintah berisi materi untuk menjalankan undang-undang sebagaimana mestinya. Dengan demikian, materi muatan peraturan pemerintah hanya menjalankan ketentuan undang-undang dan tidak membatasi hak ataupun kewajiban baru. Ketiga, Secara teoritis, sesuai dengan asas kepastian hukum, pembatasan hak WP tidak diatur dengan produk hukum berupa Peraturan Pemerintah, melainkan Undang-Undang. Keempat, Akibat ketentuan ini, secara praktis terhadap keputusan-keputusan yang dikecualikan ini tidak ada upaya hukum lebih lanjut sementara keputusan-keputusan yang dikecualikan ini diterbitkan oleh DJP sendiri. Walaupun keputusankeputusan ini diterbitkan pada level Kantor Wilayah DJP, sementara surat ketetapan pajaknya diterbitkan pada level Kantor Pelayanan Pajak, tetap saja kedua produk ini diterbitkan dalam satu payung yaitu DJP. Kelima, Ketentuan Pasal 23 ayat 2 huruf c UU KUP hanya mengecualikan keputusan yang terkait dengan Pasal 25 dan 26 UU KUP karena merupakan keputusan keberatan yang merupakan kompetensi banding. Ketentuan Pasal 23 UU KUP ini sama sekali tidak bermaksud memberikan pembatasan hak WP mengenai objek gugatan. Keenam, Surat Keputusan Pengurangan atau Pembatalan Ketetapan Pajak atau sanksi administrasi yang merupakan produk dari PK36 seharusnya tetap merupakan objek gugatan karena PK-36 ini tetap merupakan hak WP yang apabila terjadi sengketa dengan pihak fiskus seyogyanya harus diputus oleh Badan Peradilan Pajak.

\section{Hak dan Kewajiban Wajib Pajak dalam Hukum Acara Penyelesaian Sengketa di Pengadilan Pajak}

Pada bagian sebelumnya, telah dipaparkan bahwa sengketa yang diselesaikan oleh Pengadilan Pajak adalah terbatas pada sengketa yang timbul dalam bidang perpajakan antara WP atau Penanggung Pajak dengan pejabat yang berwenang sebagai akibat dikeluarkannya keputusan yang dapat diajukan Banding atau Gugatan kepada Pengadilan Pajak berdasarkan peraturan perundang-undangan perpajakan, termasuk gugatan atas pelaksanaan penagihan berdasarkan Undang-Undang Nomor 19 Tahun 2000 tentang Penagihan Pajak dengan Surat Paksa. Implisit dari ketentuan ini adalah adanya pembatasan kompetensi absolut Peradilan Pajak (Neno, 2006) dan karena itu, WP yang hendak mengajukan sengketa harus benarbenar memahami wahana yang hendak digunakan untuk penyelesaian sengketa perpajakan yang terdiri dari banding dan gugatan. Banding adalah upaya lebih lanjut dari keberatan dan objeknya adalah Keputusan Keberatan, sedangkan Gugatan adalah upaya lebih lanjut untuk sengketa yang terkait dengan penagihan pajak, Keputusan yang berhubungan dengan pelaksanaan keputusan perpajakan, dan penerbitan SKP atau SK Keberatan yang tidak memenuhi ketentuan formal.

Proses persiapan banding atau gugatan (Asmara, 2006:74) adalah dimulai dengan permohonan banding atau gugatan WP yang akan diteruskan oleh Pengadilan Pajak kepada pihak fiskus untuk mempersiapkan Surat Uraian Banding (atas Surat Banding) atau Surat Tanggapan (untuk Surat Gugatan) dalam jangka waktu empat belas (14) hari sejak diterimanya Surat Banding atau Gugatan. Pihak fiskus kemudian menyiapkan Surat Uraian Banding dalam jangka waktu tiga (3) bulan atau Surat Tanggapan dalam jangka waktu satu (1) bulan. Salinan Surat Uraian Banding atau Surat Tanggapan ini akan dikirimkan kepada pihak pemohon dalam 
waktu empat belas (14) hari. Atas dasar Surat Uraian Banding atau Surat Tanggapan ini, pihak pemohon akan mempersiapkan Surat Bantahan dalam jangka waktu satu (1) bulan. Selanjutnya, Ketua Pengadilan Pajak akan menunjuk Majelis yang akan bersidang dalam jangka waktu enam (6) bulan untuk perkara banding dan tiga (3) bulan untuk perkara gugatan sejak diterimanya surat permohonan WP.

Hukum Acara Pengadilan Pajak sebenarnya tidak jauh berbeda dengan Hukum Acara PTUN. Namun demikian, ada beberapa hal yang perlu diperhatikan karena berhubungan dengan perlindungan hukum hak dan kewajiban WP sebagai berikut:

Pertama, Aspek utama yang membedakan hukum acara di Pengadilan Pajak dengan PTUN adalah bahwa dalam PTUN dikenal adanya kompetensi relatif sedangkan kompetensi relatif ini tidak dikenal dalam Hukum Acara Pengadilan Pajak. Indikasi adanya kompetensi relatif PTUN dapat diketahui dari ketentuan Pasal 54 UU PTUN yang menyebutkan bahwa gugatan PTUN diajukan ke pengadilan yang daerah hukumnya meliputi tempat kedudukan atau tempat tinggal tergugat (Harahap, 2008:34). Sebaliknya dalam Pasal 3 UU PP ditegaskan bahwa dengan undang-undang ini dibentuk Pengadilan Pajak yang berkedudukan di Ibukota Negara. Selanjutnya Pasal 4 UU PP menegaskan lebih lanjut bahwa sidang Pengadilan Pajak dilakukan di tempat kedudukannya yaitu Ibukota Negara (Jakarta) dan apabila dipandang perlu dapat dilakukan di tempat lain. Dengan demikian, walaupun Pengadilan Pajak hingga saat ini telah ada di kota lain selain Ibukota Negara yaitu Surabaya dan Yogyakarta, hal ini hanya berarti tempat sidangnya saja dan tidak berarti tempat kedudukannya yang tetap di Jakarta. Pengajuan Surat Permohonan Banding ataupun gugatan juga masih tetap di Pengadilan Pajak Jakarta, walaupun nantinya persidangan dilakukan di kota lain.

Kedua, UU PP membedakan dua jenis sengketa yaitu banding dan gugatan yang berimplikasi pada kompetensi absolut (dalam satu lembaga yaitu Pengadilan Pajak) yang telah dijelaskan pada bagian sebelumnya. Dalam UU PTUN tidak ada pembagian lembaga ini, yang ada hanyalah gugatan perbuatan melawan hukum yang dilakukan oleh penguasa (onrechmatige overheidsdaad). Kompetensi absolut ini dalam banyak hal berarti mengurangi hak WP karena WP harus memahami kedua lembaga ini. Konsekuensinya adalah apabila terjadi kesalahan dalam pengajuan permohonan, maka permohonan
WP akan tidak dapat diterima dan tidak diproses lebih lanjut. Keberadaan dua lembaga yaitu banding dan gugatan ini tentu saja juga harus dibaca dari sisi tolok ukur objek yang menjadi pokok sengketa yaitu keputusan. Keputusan dalam Pasal 1 angka 4 UU PP didefinisikan sebagai suatu penetapan tertulis di bidang perpajakan yang dikeluarkan oleh pejabat yang berwenang berdasarkan peraturan perundangundangan perpajakan dan dalam rangka pelaksanaan Undang-Undang Penagihan Pajak dengan Surat Paksa. Dengan demikian, walaupun dari tinjauan tolok ukur subjek dan objek UU PP hampir sama dengan UU PTUN, tetap saja ada perbedaan karena adanya dua lembaga itu.

Ketiga, Berbeda dengan sengketa TUN yang memberikan jangka waktu pengajuan adalah 90 hari terhitung sejak diterimanya atau diumumkannya Keputusan yang digugat, jangka waktu pengajuan Banding adalah 3 (tiga) bulan sejak Surat Keputusan Keberatan diterima dan jangka waktu pengajuan Gugatan adalah 30 hari sejak diterimanya keputusan yang digugat, kecuali untuk keputusan yang terkait dengan penagihan pajak adalah 14 hari sejak tanggal pelaksanaan penagihan.

Keempat, Dalam aspek keputusan yang dapat diajukan gugatan, Pasal 3 UU PTUN mengenal keputusan TUN Negatif yang sebenarnya tidak ada suatu keputusan yang dikeluarkan sama sekali sedangkan Badan atau Pejabat TUN itu memiliki kewajiban untuk mengeluarkan suatu keputusan. Hal ini disamakan dengan keputusan yang isinya penolakan atas permohonan sebelumnya (Setiadi, 1994:196). UU PP tidak mengenal adanya Keputusan Negatif ini. Sebenarnya, cakupan KTUN negatif sebagai salah satu objek yang dapat digugat dapat dipertimbangkan untuk diterapkan dalam sengketa perpajakan mengingat ada beberapa permohonan WP yang tidak dijawab oleh pihak fiskus. Hal ini dapat mengakibatkan hak WP yang tidak terpenuhi oleh pihak fiskus sementara upaya hukum selanjutnya masih menjadi tanda tanya besar.

Kelima, Dalam hukum acara PTUN dikenal dengan pemeriksaan persiapan yang bertujuan untuk meneliti Surat Gugatan sehingga apabila tidak memenuhi ketentuan, penggugat masih diberikan jangka waktu 30 hari untuk memperbaiki atau melengkapi kekurangan-kekurangan Surat Gugatan (Indroharto, 1993:70). Selain pemeriksaan persiapan, dalam hukum acara PTUN juga dikenal adanya rapat 
permusyawaratan yang dapat mengandung nasihat hakim kepada penggugat untuk memperbaiki gugatannya (Wijoyo, 2005:139-140). Ketentuan yang melindungi hak penggugat seperti ini tidak dikenal di Peradilan Pajak. Namun demikian, dalam Pasal 50 ayat (3) UU PP disebut bahwa dokumen atau kelengkapan dapat disusulkan dalam persidangan kecuali yang terkait dengan persyaratan bahwa permohonan diajukan dalam bahasa Indonesia dan satu permohonan untuk satu Surat Keputusan Keberatan atau keputusan yang digugat. Di Pengadilan Pajak, apabila berdasarkan penelitian ditemukan permohonan banding atau gugatan yang tidak memenuhi ketentuan formal, maka Majelis akan mengadakan sidang acara cepat untuk memutuskan permasalahan ini.

Keenam, Dalam hukum acara PTUN dikenal adanya intervensi pihak ketiga yang masuk dalam sengketa TUN yang dapat bertindak sebagai pihak yang membela haknya atau peserta yang bergabung dengan salah satu pihak yang bersengketa. Hal ini tidak dimungkinkan dalam sengketa perpajakan karena memang dasar dari pajak adalah perikatan antara pihak fiskus dan WP sesuai dengan undang-undang.

Ketujuh, Dalam Acara Pemeriksaan di PTUN dikenal pemeriksaan dengan acara singkat dan acara cepat. Pemeriksaan dengan acara singkat di PTUN dilakukan apabila terdapat perlawanan (verset) atas penetapan yang diputuskan oleh ketua pengadilan dalam rapat permusyawaratan (Harahap, 2005:109). Pemeriksaan acara cepat dilakukan apabila terdapat kepentingan penggugat yang cukup mendesak yang harus disimpulkan dari alasan-alasan permohonan penggugat (Pasal 98 ayat (1) UU PTUN). Dalam hukum acara Peradilan Pajak hanya dikenal pemeriksaan dengan acara cepat (Pasal 66 ayat (1) UU PP) yang dilakukan terhadap: Sengketa pajak tertentu yaitu permohonan banding atau gugatan yang tidak memenuhi ketentuan formal; Gugatan yang tidak diputus dalam jangka waktu 6 bulan; Tidak dipenuhinya salah satu ketentuan dalam Putusan Pengadilan Pajak atau kesalahan tulis dan/atau kesalahan hitung dalam Putusan Pengadilan Pajak; serta Sengketa yang berdasarkan pertimbangan hukum bukan merupakan wewenang Pengadilan Pajak.

Walaupun dalam konteks UU KUP yang baru, pengajuan Keberatan dan Banding menangguhkan jumlah pajak yang belum dibayar pada saat pengajuan keberatan sesuai Pasal 25 ayat (7) dan (8) UU KUP, pengaturan persidangan acara biasa dan acara cepat dalam Pengadilan Pajak ini dapat berimplikasi pada perlindungan hak WP yang lemah terutama dalam hal adanya upaya penagihan ketetapan pajak (baik STP maupun SKP) sesuai dengan UU tentang Penagihan dengan Surat Paksa. Dalam hal ini, penangguhan pembayaran jumlah pajak tersebut tidak berlaku untuk produk hukum berupa STP. Hal ini disebabkan karena WP hanya memiliki jalan berupa gugatan untuk pelaksanaan penagihan yang akan diproses dalam jangka waktu 6 bulan sedangkan pengajuan gugatan sama sekali tidak menunda proses penagihan.

Kedelapan, Perbedaan yang memiliki dampak paling signifikan terhadap hak dan kewajiban WP adalah upaya hukum lebih lanjut dari putusan pengadilan. Dalam PTUN upaya hukum yang dapat ditempuh oleh para pihak yang bersengketa dalam penyelesaian sengketa TUN adalah Perlawanan, Banding dan Kasasi yang merupakan upaya hukum biasa serta upaya Peninjauan Kembali yang merupakan upaya hukum luar biasa (Harahap, 2008:165). Hal ini sejalan dengan ketentuan Pasal 86 UU PP yang menyebutkan bahwa Putusan Pengadilan Pajak dapat langsung dilaksanakan dengan tidak memerlukan lagi keputusan pejabat yang berwenang kecuali peraturan perundang-undangan mengatur lain. Selain itu, Pasal 66 ayat (2) UU PP juga menyebutkan hal yang sama bahwa permohonan Peninjauan Kembali tidak menangguhkan atau menghentikan pelaksanaan putusan pengadilan. Namun demikian, hakikat ini dalam praktik sering diabaikan seperti misalnya ada kasus yang mana pihak Kantor Pajak menolak untuk melaksanakan putusan Pengadilan Pajak untuk memberi pengembalian pajak hanya dengan alasan bahwa atas Putusan Pengadilan Pajak itu telah diajukan Peninjauan Kembali ke MA, sehingga eksekusi itu ditunda hingga Putusan Peninjauan Kembali telah diterima oleh pihak DJP. Lebih lanjut lagi, hakikat ini juga tampaknya disimpangi dengan beberapa ketentuan dalam PP No. 74 Tahun 2011 sebagai berikut:

Pertama, Pasal 36 ayat (4) yang menyebutkan bahwa DJP secara jabatan mengurangkan atau membatalkan sanksi administrasi dalam STP yang diterbitkan sebagai akibat dari penerbitan SKP yang diajukan Keberatan, Banding, Peninjauan Kembali, pengurangan atau pembatalan SKP dan telah diterbitkan SK Keberatan, Putusan Pengadilan Pajak, Putusan Peninjauan Kembali, Surat Keputusan Pengurangan atau Pembatalan Surat Ketetapan Pajak.

Kedua, Pasal 42 ayat (2) yang menyebutkan bahwa DJP menerbitkan Surat Pelaksanaan Putusan 
Peninjauan Kembali setelah menerima Putusan Peninjauan Kembali.

Ketiga, Pasal 43 ayat (6) huruf c yang menyebutkan bahwa dalam hal putusan Banding diajukan permohonan Peninjauan Kembali, imbalan bunga diberikan apabila Putusan Peninjauan Kembali telah diterima oleh DJP dari MA.

Berdasarkan ketentuan-ketentuan tersebut, jelas sekali bahwa hakikat Putusan Peninjauan Kembali sudah bukan lagi hasil dari upaya hukum luar biasa. Ketentuan-ketentuan ini sebenarnya tidak terlalu adil dalam aspek pemenuhan hak WP, mengingat waktu penyelesaian sengketa Peninjauan Kembali di MA yang dapat memakan waktu yang relatif lama. Hak WP bisa saja tidak terlindungi apabila sengketa terkait dengan upaya penagihan aktif yang dilakukan oleh DJP, karena dalam PP-74 Tahun 2011 sama sekali tidak diatur bahwa upaya penagihannya akan ditunda hingga dikeluarkannya Putusan Peninjauan Kembali.

Terlepas dari inkonsistensi ini, dalam sengketa perpajakan, upaya hukum yang dapat ditempuh setelah Putusan Pengadilan Pajak hanyalah upaya Peninjauan Kembali. Hal ini secara implisit berarti adanya reduksi atau pengurangan fungsi yudikatif dalam sistem peradilan pajak. Syofrin Syofyan dan Asyhar Hidayat (2004:99) menyatakan bahwa eksistensi (fungsi) pengadilan pajak menurut UU PP tidak berlaku dengan sistem peradilan yang berlaku karena peradilan pajak tidak menerapkan upaya hukum pada tingkat kasasi. Karena itu, MA sebagai lembaga judicial control tertinggi tidak dapat menggunakan kewenangannya secara optimal dalam Peradilan Pajak.

\section{PENUTUP}

\section{Kesimpulan}

Secara umum, prosedur penyelesaian sengketa perpajakan setelah upaya keberatan atau PK-36 adalah upaya banding atau gugatan ke Pengadilan Pajak. Hakikat Pengadilan Pajak diposisikan sebagai lembaga peradilan khusus di lingkungan PTUN. Namun demikian, intervensi kekuasaan eksekutif dalam Pengadilan Pajak masih tetap ada dalam hal pembinaan organisasi, administrasi, dan keuangan.

Dalam konteks hak dan kewajiban WP, kekhususan Pengadilan Pajak ini cenderung diartikan seluas-luasnya mulai dari adanya pembedaan kompetensi absolut yaitu upaya Banding dan Gugatan, hukum acara yang berbeda, dan kesempatan upaya hukum lebih lanjut yang terpangkas karena putusan Pengadilan Pajak hanya bisa diajukan Peninjauan Kembali ke MA.

\section{Rekomendasi}

Mengharapkan pembaharuan peradilan pajak yang ekslusif, transparan, dan akuntabilitas yang berasaskan peradilan yang sederhana, cepat, dan murah sehingga pencari keadilan bisa dilaksanakan.

\section{DAFTAR PUSTAKA \\ Buku:}

Asmara, Galang. 2006. Peradilan Pajak dan Lembaga Penyanderaan (Gijzeling) dalam Hukum Pajak Indonesia. Yogyakarta: LaksBang Pressindo.

Badrulzaman, Mariam Darus, Sutan Remy Sjahdeini, Heru Soepraptomo, Faturrahman Djamil, dan Taryana Soenandar. 2001. Kompilasi Hukum Perikatan: Dalam Rangka Memperingati Memasuki Masa Purna Bakti Usia 70 Tahun. Bandung: Citra Aditya Bakti.

Basah, Sjachran. 1997. Eksistensi dan Tolok Ukur Badan Peradilan Administrasi di Indonesia. Bandung: Alumni.

Brotodihardjo, R. Santoso. 2008. Pengantar Ilmu Hukum Pajak. Bandung: Refika Aditama.

Fuady, Munir. 2013. Teori-teori Besar (Grand Theory) dalam Hukum. Jakarta: Kencana Prenada Media.

Harahap, Zairin. 2005. Hukum Acara Peradilan Tata Usaha Negara. Edisi Revisi. Jakarta: Rajawali Pers.

Ikatan Konsultan Pajak Indonesia. 2012. Catatan Berkenaan dengan PP-74 (tidak diterbitkan).

Indroharto. 1999. Usaha Memahami Undang-undang tentang Peradilan Tata Usaha Negara. Buku II. Jakarta: Pustaka Sinar Harapan.

Kelsen, Hans. 2006. Teori Hukum Murni (terjemahan).

Bandung: Nuansa dan Nusamedia. 2006. Teori Umum tentang Hukum dan Negara (terjemahan). Bandung: Nuansa dan Nusamedia.

Kementerian Keuangan - Direktorat Jenderal Pajak. 2010. Reformasi Pajak: Silent Revolution. Jakarta: DJP.

Marzuki, Peter Mahmud. 2006. Pengantar Ilmu Hukum. Jakarta: Kencana Prenada Media.

Neno, Victor Yaved. 2006. Implikasi Pembatasan Kompetensi Absolut Peradilan Tata Usaha Negara. Bandung: Citra Aditya Bakti. 
Pudyatmoko, Y. Sri. 2009. Pengadilan dan Penyelesaian Sengketa di Bidang Pajak. Jakarta: Gramedia Pustaka Utama.

Setiadi, Wicipto. 1994. Hukum Acara Peradilan Tata Usaha Negara: Suatu Perbandingan. Jakarta: RajaGrafindo Persada.

Soemitro, Rochmad. 1976. Masalah Peradilan Administrasi dalam Hukum Pajak di Indonesia. Bandung: Eresco. . 1990. Asas dan Dasar Perpajakan 1. Bandung Eresco.

Syofyan, Syofrin dan Asyhar Hidayat. 2004. Hukum Pajak dan Permasalahannya. Bandung: Refika Aditama.

Widodo, Widi dan Dedy Djefris. 2008. Tax Payer's Rights: Apa yang Perlu Kita Ketahui tentang Hak-hak Wajib Pajak. Bandung: Alfabeta.

Wijoyo, Suparto. 2005. Karakteristik Hukum Acara Peradilan Administrasi (Peradilan Tata Usaha Negara). Surabaya: Airlangga University Press.

\section{Peraturan Perundang-undangan:}

Undang-Undang Nomor 6 Tahun 1983 sebagaimana telah beberapa kali diubah terakhir dengan UndangUndang Nomor 16 Tahun 2009 tentang Ketentuan Umum dan Tata Cara Perpajakan.

Undang-Undang Nomor 14 Tahun 2002 tentang Pengadilan Pajak.
Undang-Undang Nomor 51 Tahun 2009 tentang Perubahan Kedua atas Undang-Undang Nomor 5 Tahun 1986 tentang Peradilan Tata Usaha Negara.

Undang-Undang Nomor 12 Tahun 2011 tentang Pembentukan Peraturan Perundang-undangan.

Peraturan Pemerintah Nomor 74 Tahun 2011 tentang Tata Cara Pelaksanaan Hak dan Pemenuhan Kewajiban Perpajakan.

\section{Putusan Pengadilan:}

Putusan Pengadilan Pajak Nomor Putusan 32465/PP/ M.XIII/15/2011.

Putusan Pengadilan Pajak Nomor Putusan 37999/ PP/M.I/99/2012.

Putusan Mahkamah Konstitusi Perkara Nomor 004/ PUU-II/2004.

\section{Jurnal/Artikel:}

Eddy, John, Undang-Undang Pengadilan Pajak, Inkonstitusional atau Batal Demi Hukum? Bisnis Indonesia (tanpa tanggal dan tahun).

Marbun, Rocky. 2012. Eksistensi Pengadilan Pajak dalam Kekuasaan Kehakiman di Indonesia. Diunduh dari http://forumduniahukumblogku. wordpress.com/2012/12/24/eksistensi-pengadilanpajak-dalam-kekuasaan-kehakiman-di-indonesia. tanggal 31 Desember 2012

Von Bernstorff, Jochen. 2012. Georg Jellinek and the Origins of Liberal Constitutionalism in International Law. Goettingen Journal of International Law 4. 